DOI: 10.1002/ejoc.200500892

\title{
Conjugated Azomethine Ylides
}

\author{
Teresa M. V. D. Pinho e Melo*[a]
}

Keywords: Vinyl azomethine ylides / Butadienyl azomethine ylides / Azafulvenium methides / Electrocyclization / 1,3Dipolar cycloaddition / Sigmatropic shift

The 1,3-dipolar cycloaddition of azomethine ylides is an efficient and versatile tool for the construction of five-membered nitrogen-heterocycles. When the azomethine ylide is conjugated with a double bond or a 1,3-diene moiety, other reactivity pathways are also available, namely 1,5-electrocyclization or 1,7-electrocyclization. The present review is fo- cused on the generation and reactivity of this type of dipoles, which offer general strategies for the formation of five- and seven-membered nitrogen-heterocyclic compounds.

(® Wiley-VCH Verlag GmbH \& Co. KGaA, 69451 Weinheim, Germany, 2006)

\section{Introduction}

The impressive work by Huisgen et al. in the early 1960s led to the classification of 1,3-dipoles, and to the general concept of 1,3-dipolar cycloaddition reactions. ${ }^{[1]}$ Based on the concept of the conservation of orbital symmetry developed by Woodward and Hoffmann, ${ }^{[2]}$ Houk et al. also gave an important contribution to the understanding of the reactivity and regioselectivity of 1,3-dipolar cycloadditions. ${ }^{[3]}$ Since then, this reaction has become an important and general route to the construction of five-membered heterocyclic ring systems. ${ }^{[4-9]}$

Azomethine ylides are 1,3-dipoles of the allyl anion type, having four $\pi$ electrons spread over the three-atom $\mathrm{C}-\mathrm{N}-\mathrm{C}$ unit. They can be represented by four zwitterionic resonance forms (1). The two octet structures, the most common representation, illustrate the allyl anion character with a positive nitrogen atom, an iminium centre, and a negative

[a] Departamento de Química, Universidade de Coimbra, 3004-535 Coimbra, Portugal

Fax: +351-239-826068

E-mail: tmelo@ci.uc.pt charge distributed over the two carbon atoms. The sextet structures symbolise the electrophilic and nucleophilic character at the termini of the dipole.<smiles></smiles>

1

Azomethine ylides participate in 1,3-dipolar cycloadditions as electron-rich dipoles. Thus, in terms of frontier molecular orbitals, the dominant interaction involves the highest occupied molecular orbital (HOMO) of the azomethine ylide and the lowest unoccupied molecular orbital (LUMO) of the dipolarophile. The energies of the frontier orbitals for the parent azomethine ylide $\mathbf{2}$ and for the more electron-deficient derivative $\mathbf{3}$ have been estimated (Figure 1). The parent azomethine ylide has approximate energies of $-6.9 \mathrm{eV}$ for the HOMO and $+1.4 \mathrm{eV}$ for the LUMO. The most favourable orbital interaction will be between the HOMO of this dipole and the LUMO of an electron-deficient dipolarophile. However, due to the narrow frontier orbital separation, the interaction of the parent azomethine

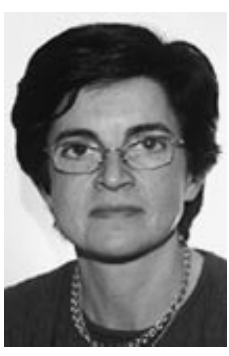

Teresa M. V. D. Pinho e Melo was born in Portugal in 1962. She studied Chemistry at the University of Coimbra, where she graduated in 1985. She got her M.Sc. in 1991 and her Ph.D. in Organic Chemistry in 1995. She received her Habilitation in Organic Chemistry in 2003. She is currently Professor with Habilitation at the University of Coimbra. Her research interests are in the area of synthetic and mechanistic heterocyclic organic chemistry.

MICROREVIEWS: This feature introduces the readers to the authors' research through a concise overview of the selected topic. Reference to important work from others in the field is included. 
ylide LUMO and the HOMO of an electron-rich $\pi$-system cannot be ruled out. The azomethine ylide, $\mathbf{3}$, bearing two electron-withdrawing groups, has a HOMO energy of $-7.7 \mathrm{eV}$ and a LUMO energy of $-0.6 \mathrm{eV}$. In this case, the energy gap is even narrower, and the dipole should react with any type of dipolarophile. Therefore, the substitution pattern of the azomethine ylide is very important in determining its chemical behaviour. Prediction of the regioselectivity of the 1,3-dipolar cycloaddition can be made based on the values of the orbital coefficients of the terminal carbons, although steric effects usually also play an important role. ${ }^{[3-9]}$

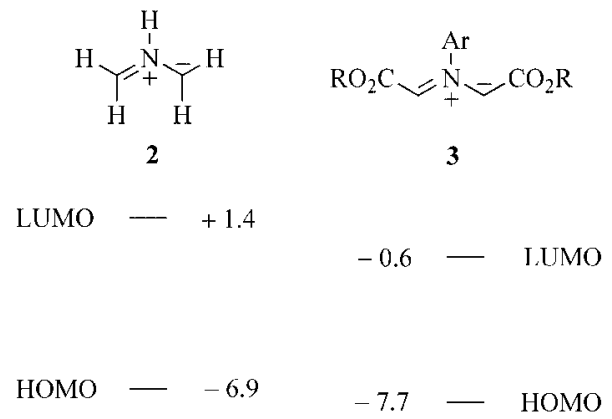

Figure 1. Estimated frontier orbital energies for azomethine ylides 2 and 3

Pyridinium ylides were the first azomethine ylides to be studied systematically. In 1934 Kröhnke reported the synthesis of the crystalline carbonyl-stabilised pyridinium ylide 5 by base-promoted deprotonation of pyridinium salt 4 . The same author described the generation of the nonstabilised pyridinium ylide 7, which cannot be isolated. However, azomethine ylide 7 can be trapped by condensation with aldehydes, or via 1,3-dipolar cycloaddition on reacting with dipolarophiles. Nevertheless, the pyridinium ylides are significantly more stable than analogous azomethine ylides where the iminium subunit is not part of an aromatic ring. Since then, cycloaddition reactions of pyridinium ylides have been further studied, and have became an interesting route to indolizine derivatives (Scheme 1) ${ }^{[9-13]}$

The reactivity pattern of conjugated azomethine ylides includes not only their reactivity as 1,3-dipoles in 1,3-dipolar cycloadditions, but they can also undergo sigmatropic

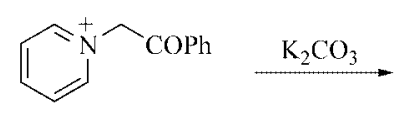

4

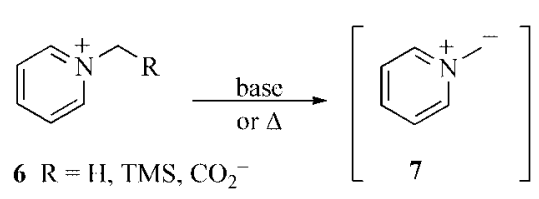

shifts and electrocyclization reactions. That is the case for vinyl azomethine ylides, which can be represented by the resonance forms $\mathbf{1 0}$, with the octet structure revealing the resonance of the pentadienyl anion type. Thus, when the azomethine ylide is conjugated with a double bond (10) or a 1,3-diene moiety (11), products from 1,5- or 1,7-electrocyclization can be obtained. The present review will focus on the generation and reactivity of this type of azomethine ylides (Scheme 2).

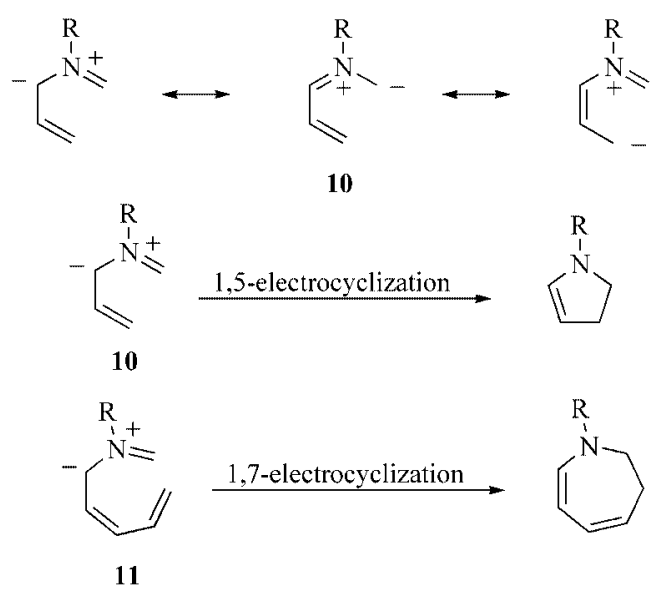

Scheme 2.

\section{Vinyl Azomethine Ylides and Butadienyl Azomethine Ylides}

Earlier reviews on 1,5-dipolar cyclizations covered the most significant synthetic pathways to vinyl azomethine ylides known at that time. ${ }^{[14,15]}$ The electrocyclic ring opening of vinyl aziridines (12) is one approach to these types of dipoles, and their 1,5-electrocyclization gives pyrroline derivatives. Pyridinium allylides can be deprotonated under mild basic conditions to give vinyl pyridinium ylides, 14, which are useful precursors of indolizines via 1,5-electrocyclization. Other quaternary salts derived from alkylation of nitrogen heterocycles such as quinoline, benzimidazole and pyridizine show similar chemical behaviour. Vinyl azomethine ylides can also be generated from enamines. This pro-<smiles>CC(O)C[n+]1ccccc1</smiles><smiles>COC(=O)c1c(C(C)=O)cn2ccccc12</smiles>

Scheme 1 . 
cess is illustrated using 3-pyrrolidinothiophene (15) as the starting enamine. ${ }^{[16]}$ The reaction with dimethyl acetylenedicarboxylate (DMAD) in methanol leads to the formation<smiles>[R]N1CC1C=C</smiles>

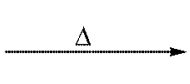

12<smiles>[Y][C@H](C=C)[n+]1ccccc1</smiles>

13<smiles>[R]/[N+](C)=C/C=C</smiles>

10<smiles>[R]C(C=C)[n+]1ccccc1</smiles>

14<smiles>[R]C1=C([R])C(=[N+]2CCCC2)C(C(=CC(C)=O)C(C)=O)S1</smiles>

16<smiles>[R]c1scc(N2CCCC2)c1[R]</smiles><smiles>COC(C)(C)C</smiles><smiles>C=C</smiles><smiles>[R]C1=C([R])[C@H]([N+]2=CCCC2)/C(=C(\CC(C)=O)C(C)=O)S1</smiles>
17

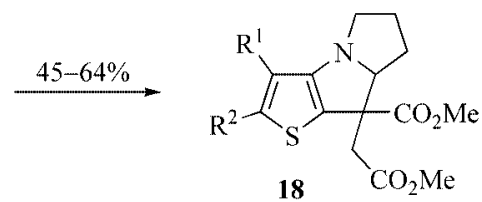

of an azomethine ylide, which tautomerises to the vinyl azomethine ylide 17. The 1,5-electrocyclization of this dipole produces the corresponding tricyclic heterocyclic ring system 18 (Scheme 3).

The rearrangement of aziridine $\mathbf{1 9}$ to give imine $\mathbf{2 1}$ can be followed by ${ }^{1} \mathrm{H}$ NMR spectroscopy. Thus, the conjugated azomethine ylide is generated from the thermal ring opening of the aziridine, and it tautomerises to the corresponding imine. Azomethine ylide 20 participates in 1,3dipolar cycloaddition reactions with a range of dipolarophiles in an endo-selective process. The trans-aziridine undergoes a conrotatory ring opening to give the $\mathrm{W}$ dipole, and its cycloaddition leads to cis-2,3-disubstituted pyrrolidines (22). The vinylogous ester acts as a stabilizing group for the azomethine ylide (Scheme 4). ${ }^{[17]}$

A similar reactivity was observed when aziridine $\mathbf{2 3}$ was heated in the presence of diethyl fumarate. The vinyl azomethine ylide 24, generated in situ, affords the corresponding 1,3-cycloadduct in $49 \%$ yield (Scheme 5). ${ }^{[18]}$

Eberbach et al. described the use of 2,3-dihydroisoxazoles as precursors of conjugated azomethine ylides. In fact, the thermolysis of the bicyclic 2,3-dihydroisoxazoles 26, carried out in benzene at $280-320{ }^{\circ} \mathrm{C}$ for $10 \mathrm{~s}$, gave bicyclic dihydroazepines $30(42-59 \%)$ as the main products, together with the formation of 1,2-annulated pyrroles 32 (3$9 \%$ ). A known reactivity feature of 2,3-dihydroisoxazoles is the ring transformation into acylaziridines. Thus, compounds $\mathbf{2 6}$ are converted into aziridines $\mathbf{2 7}$, which undergo ring cleavage to give conjugated azomethine ylides 28 . The 1,7-electrocyclization of these dipoles leads to the dihydroazepine derivatives, whereas the 1,5-electrocyclic reaction leads to the pyrroles (Scheme 6). ${ }^{[19]}$

Similar chemistry can be carried out with enynyl-substituted 2,3-dihydroisoxazoles $\mathbf{3 3}$ and $\mathbf{3 4}$. These compounds can also act as masked conjugated azomethine ylides. Depending on the terminal substituent of the enynyl sidechain, either 1,5- or 1,7-electrocyclization is observed. Thus,

Scheme 3.

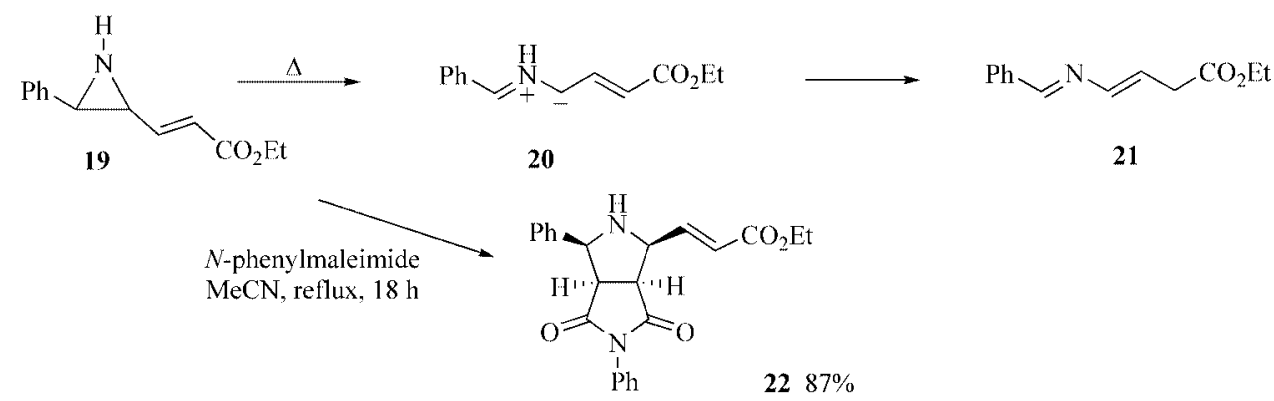

Scheme 4.

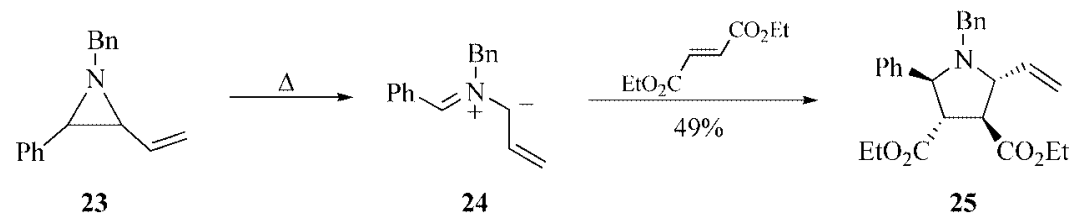

Scheme 5. 


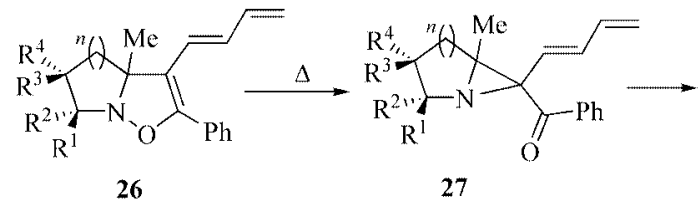

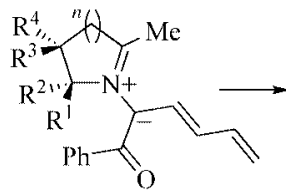

28

$\mathrm{R}^{1}=\mathrm{R}^{2}=\mathrm{Me} ; \mathrm{R}^{3}=\mathrm{R}^{4}=\mathrm{H} ; n=1$

$\mathrm{R}^{1}=\mathrm{R}^{2}=\mathrm{H} ; \mathrm{R}^{3}=\mathrm{R}^{4}=\mathrm{Me} ; n=1$

$\mathrm{R}^{\mathrm{I}}=\mathrm{R}^{2}=\mathrm{R}^{3}=\mathrm{R}^{4}=\mathrm{H} ; n=2$

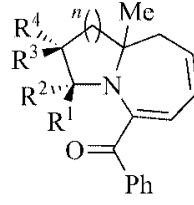

$30 \quad 42-59 \%$

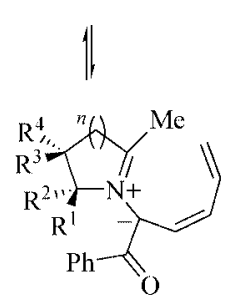

29

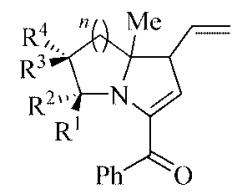

31

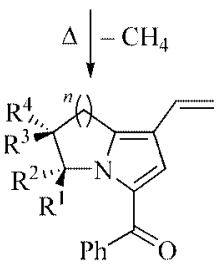

$323-9 \%$

Scheme 6.

the 2,3-dihydroisoxazoles $\mathbf{3 3}$ allow the construction of fivemembered ring systems, whereas compounds $\mathbf{3 4}$ afford seven-membered ring systems. ${ }^{[20]}$

$$
\begin{aligned}
& \mathrm{R}=\mathrm{Ph} \text { or } t \mathrm{Bu} \\
& \text { (M) } \\
& \text { 33a } \mathrm{R}^{1}=\mathrm{R}^{2}=\text { Me; } \mathrm{R}^{3}=\mathrm{R}^{4}=\mathrm{H} ; n=1 \\
& \text { b } \mathrm{R}^{1}=\mathrm{R}^{2}=\mathrm{H} ; \mathrm{R}^{3}=\mathrm{R}^{4}=\mathrm{Me} ; n=1 \\
& \text { c } \mathrm{R}^{1}=\mathrm{R}^{2}=\mathrm{R}^{3}=\mathrm{R}^{4}=\mathrm{H} ; n=2 \\
& \text { (1/f } \\
& \text { 34a } \mathrm{R}^{1}=\mathrm{R}^{2}=\mathrm{Me} ; \mathrm{R}^{3}=\mathrm{R}^{4}=\mathrm{H} ; n=1 \\
& \text { b } \mathrm{R}^{1}=\mathrm{R}^{2}=\mathrm{H} ; \mathrm{R}^{3}=\mathrm{R}^{4}=\mathrm{Me} ; n=1 \\
& \text { c } \mathrm{R}^{1}=\mathrm{R}^{2}=\mathrm{R}^{3}=\mathrm{R}^{4}=\mathrm{H} ; n=2
\end{aligned}
$$

The structure of the vinyl azomethine ylide 35 , an isolable compound, is embedded in two aromatic rings. The 1,5-electrocyclization of $\mathbf{3 5}$, followed by $\mathrm{HNO}_{2}$ elimination in the presence of piperidine, gives the benzo $[a]$ indolizine 37 in high yield (Scheme 7). ${ }^{[21]}$

1,7-Electrocyclization of butadienyl pyridinium ylides as a route to 1,7-annulated 2,3-dihydroazepine has been described (Scheme 8). Treatment of the pyridinium salts 38 with potassium tert-butoxide in boiling THF/ $\mathrm{CH}_{3} \mathrm{CN}$ generates the dipoles 39. The stereochemistry of the products, 40, indicates that the $\pi$ ring closure of these extended dipoles takes place by a conrotatory process. No evidence of a competing 1,5-electrocyclization was observed. On the basis of quantum mechanical calculations, the authors concluded that the 1,7-electrocyclization is favoured over the 1,5-electrocyclization by both thermodynamic and kinetic factors. ${ }^{[22,23]}$

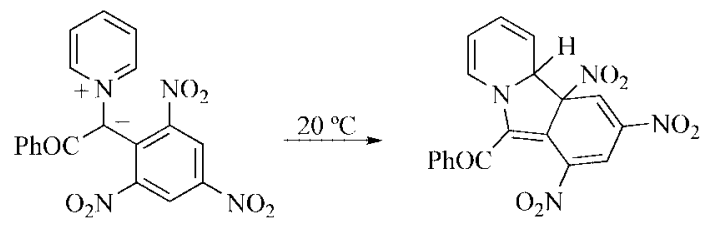

35

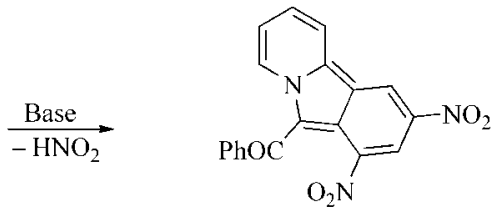

$3796 \%$

Scheme 7.

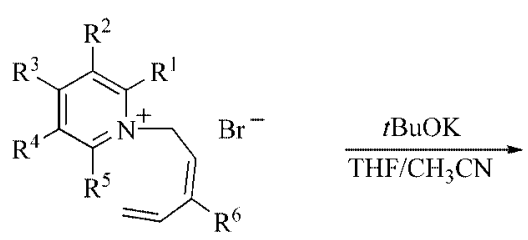

38

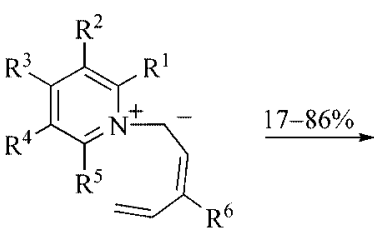

39<smiles>[R]C1=CC[C@@]2([R2])C=C([R])C([R])=C([R])N2C=C1</smiles>

40

Scheme 8 .

The conjugated pyridinium ylides $\mathbf{4 1}$ undergo $8 \pi$ electrocyclization reactions to produce heterocyclic allenes $\mathbf{4 2}$. In the presence of $\mathrm{H}_{2} \mathrm{O}$ or $\mathrm{H}_{2} \mathrm{O}_{2}$, these intermediates are converted into pyrido[1,2- $a]$ azepinones $\mathbf{4 3}$ in moderate yields (Scheme 9). ${ }^{[24]}$ 
<smiles>[R]c1cc[n+](C/C=C(/C)C#C)cc1[R]</smiles>

41a $\mathrm{R}=\mathrm{H}$

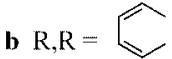

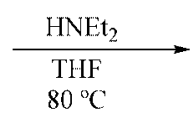

$\frac{\mathrm{H}_{2} \mathrm{O}}{\text { or } \mathrm{H}_{2} \mathrm{O}_{2}}$<smiles></smiles>

43a $55 \%$

b $50 \%$

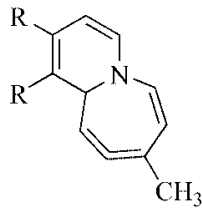

42
Scheme 9.

The thermolysis of dienamine 44a, prepared from the reaction of $\alpha$-cyanoenamines and DMAD in the presence of acrylonitrile or $N$-phenylmaleimide, leads exclusively to the corresponding 1,3-dipolar cycloadduct $\mathbf{4 6}$, which undergoes elimination of $\mathrm{HCN}$ to give the final product $\mathbf{4 7}$ or $\mathbf{4 8}$. Using the same reaction conditions, the pyrrolo-substituted diene 44b affords a product via 1,3-dipolar cycloaddition, but the vinyl azomethine ylide participates also in a 1,5electrocyclization reaction to give compound 49 as the minor product (Scheme 10). ${ }^{[25]}$ The mechanism of the reaction of 44a in the presence of acrylonitrile has been theoretically studied using ab initio methods. The larger barrier associated with the 1,5-electrocyclization reaction of the vinyl azomethine ylide intermediate 45a compared to that for the 1,3-dipolar cycloaddition with acrylonitrile justifies the formation of the 1,3-dipolar cycloadduct exclusively. ${ }^{[26]}$

Thermal isomerization of 1-(dimethylamino)-1,3,4pentatrienes $\mathbf{5 1}$ yields conjugated azomethine ylide derivatives 52, which react via 1,7-electrocyclization to form azepine products. In fact, by heating a solution of four-membered-ring compound $\mathbf{5 0}$ in tetrachloroethene at reflux, the complete conversion into 2,3-dihydroazepines $\mathbf{5 3}$ is achieved (Scheme 11). ${ }^{[27]}$

Morpholinoallenes 54 are converted in high yields into 3,4,5,12b-tetrahydro- $1 H$-[1,4]oxazino[4,3-a][2]benzazepines (55) upon sealed-tube thermolysis at $120-130^{\circ} \mathrm{C}$. The process begins with a hydrogen 1,4-shift to the central allenic carbon atom, giving the conjugated azomethine ylide 56, followed by a 1,7-electrocyclization and rearomatisation. ${ }^{[28]}$ This chemistry is not restricted to morpholinoallenes, and this azomethine ylide route to azepines can also be carried

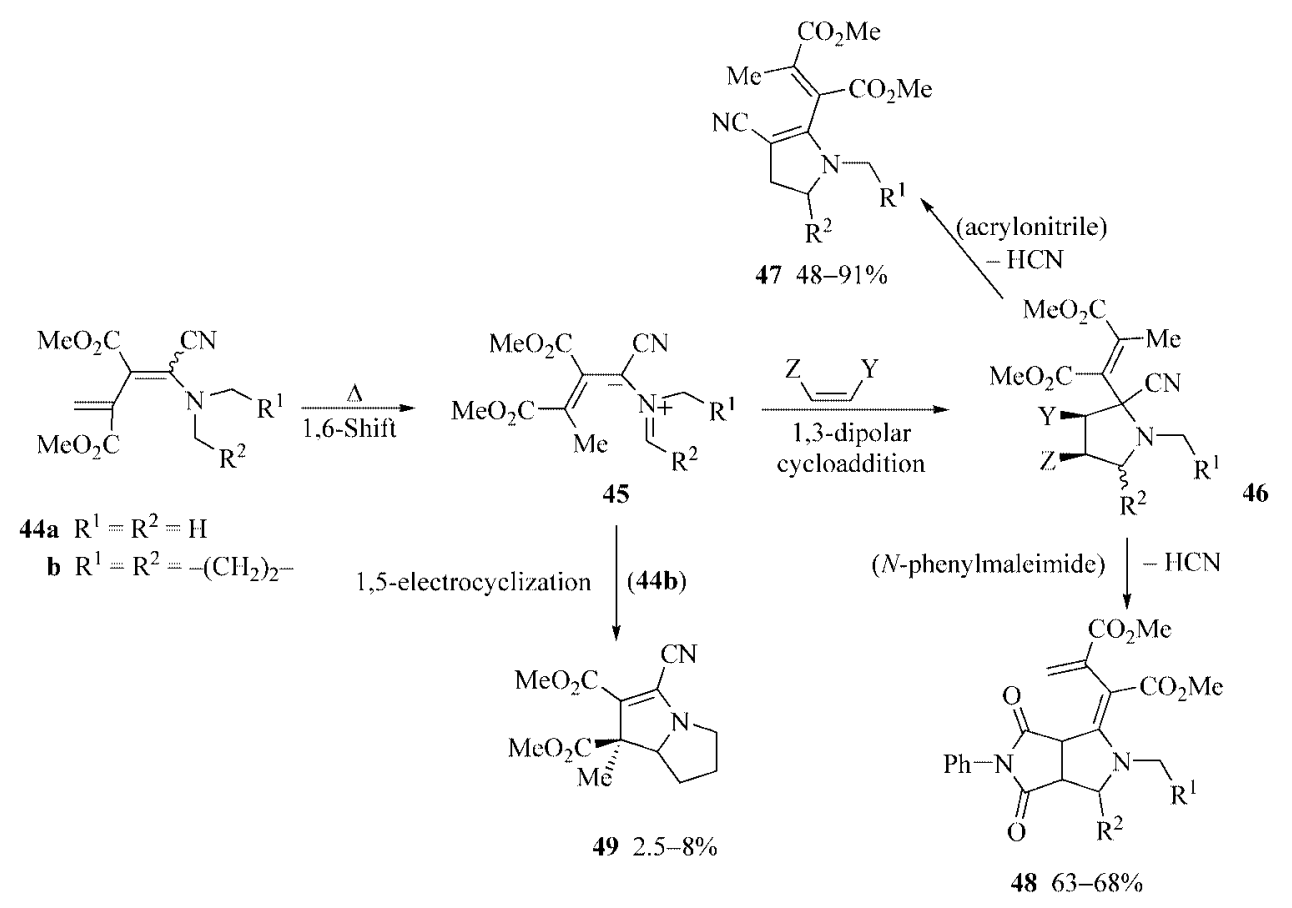

Scheme 10<smiles>[R]C1=C(C(=O)O)C(N(C)C)C1=C</smiles>

50
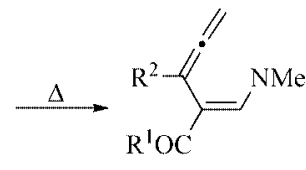

51<smiles>C1CCCCC1</smiles>

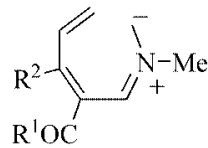

52<smiles>[R]C1=CCCN(C)C=C1C(=O)O</smiles>

53

Scheme 11 
out with other $\mathrm{N}$-methyl-substituted 2-amino-1,3-dienes. The conversion of 3,3-dimethylindoline-derived allene $\mathbf{5 8}$ to the corresponding tetracyclic azepine derivative $\mathbf{5 9}$ is an illustrative example (Scheme 12). ${ }^{[29]}$<smiles>[R]/C(=C\C(=O)N1CCOCC1)c1ccccc1</smiles>

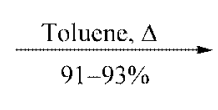<smiles>[R]/C(=C/C([R]c1ccccc1)=[N+]1CCOCC1)c1ccccc1</smiles>

56<smiles>CN1C(=C=C(CC(C)(C)C)c2ccccc2)C(C)(C)c2ccccc21</smiles>

58
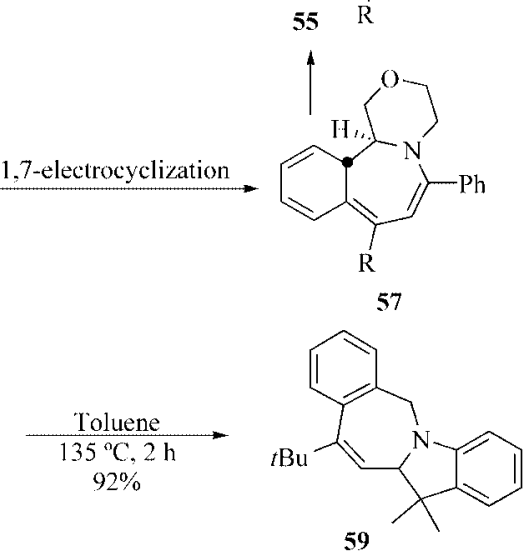

Scheme 12

The conjugated azomethine ylide generated from an $\mathrm{N}$ methyl-substituted allene with a phosphanyl or a phosphoryl group at C-3 shows a different periselectivity of the electrocyclic ring closure, and the 1,5-electrocyclization reaction becomes a competitive or dominant pathway. In fact, 1morpholino-1,3-diaryl-3-diphenylphosphanylallene (60a) is converted into annulated 3,5-diarylpyrrole 61a and annulated benzo[c]azepine 62. Allenes bearing a diphenylphosphoryl group show periselectivity markedly shifted toward 1,5-cyclization. One example is presented in Scheme 13 (the $\mathrm{PPh}_{2}$ substituent of $\mathbf{6 2}$ was oxidized to the phosphane oxide to allow the chromatographic separation). ${ }^{[30]}$

It is known that under flash vacuum pyrolysis (FVP), methylene Meldrum's acid derivatives lose acetone and carbon dioxide to generate methylene ketene intermediates. Starting with $N, N$-disubstituted aminomethylene derivatives of Meldrum's acid (63), FVP allows the generation of the conjugated azomethine ylides 65. Cyclization of these dipoles affords pyrrolo-3(2H)-ones 67 (Scheme 14). ${ }^{[31-33]}$<smiles>[R]C([R])[C@H](C)N([R])C=C1C(=O)OC(C)(C)OC1=O</smiles>

63<smiles>[R]N1C=CC(=O)C1([R])[R]</smiles>

66<smiles>[R]CC([R])[N+]([R])=CC(=O)C=O</smiles>

64
65
Scheme 14.

Under FVP reaction conditions, Meldrum's acid derivatives of type 68 lead to $1 H$-azepine-3(2H)-ones 71, together with the formation of cyclopentadienone dimer $\mathbf{7 4}$. The formation of $\mathbf{7 4}$ can be rationalised by considering the initial cycloaddition of azomethine ylide $\mathbf{7 0}$ across the carbonyl component of the ketene to give the bicyclic intermediate 72, which is converted into cyclopentadienone, and finally to the corresponding dimer (Scheme 15). ${ }^{[34]}$

The rhodium-catalyzed reaction of methyl styryldiazoacetate (75) with imines $\mathbf{7 6}$ leads to the formation of dihydropyrroles $\mathbf{7 7}$ and/or dihydroazepines $\mathbf{7 8}$. The process involves the generation of a conjugated azomethine ylide, $\mathbf{8 0}$, by the reaction of Rh-carbenoid species $\mathbf{7 9}$ with imines 76, followed by an electrocyclization reaction. The reaction of 76a affords the azepine 78a as the single product, while 76b produces a 1:2 mixture of products (Scheme 16). ${ }^{[35,36]}$

With a change the stoichiometry of the reaction of $\mathrm{N}$ benzylideneanilines with methyl styryldiazoacetates, a different outcome is observed. In fact, bicyclic pyrrolidines $\mathbf{8 2}$ are obtained when 2.0 equiv of $\mathbf{7 5}$ is used. This reactivity pattern can be illustrated by the reaction shown in Scheme 17. The synthesis of $\mathbf{8 2}$ can be explained by considering the in situ generation of azomethine ylide 83, followed by the reaction with a second metal carbenoid prior to cyclization. ${ }^{[37]}$

The stereoselective synthesis of heterocycle-annulated azepine derivatives $\mathbf{8 9}$ has been reported. The heterocyclic systems studied included pyrimidines, 1-benzopyrans, 2-pyridones and pyrido[1,2-a]pyrimidines. The PM3 molecular orbital calculations are in agreement with two consecutive

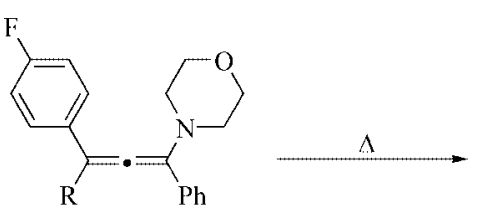

60a $\mathrm{R}=\mathrm{PPh}_{2}$ b $R=P(O) P h_{2}$<smiles>Fc1ccc(-c2cc(-c3ccccc3)n3c2COCC3)cc1</smiles>

61a $28 \%$

b $66 \%$<smiles>[CH][C@H]1C=C(C)c2ccc(F)cc2C2COCCN21</smiles>

$\mathrm{Ph}_{2}(\mathrm{O}) \mathrm{P}$

$6218 \%$

Scheme 13. 


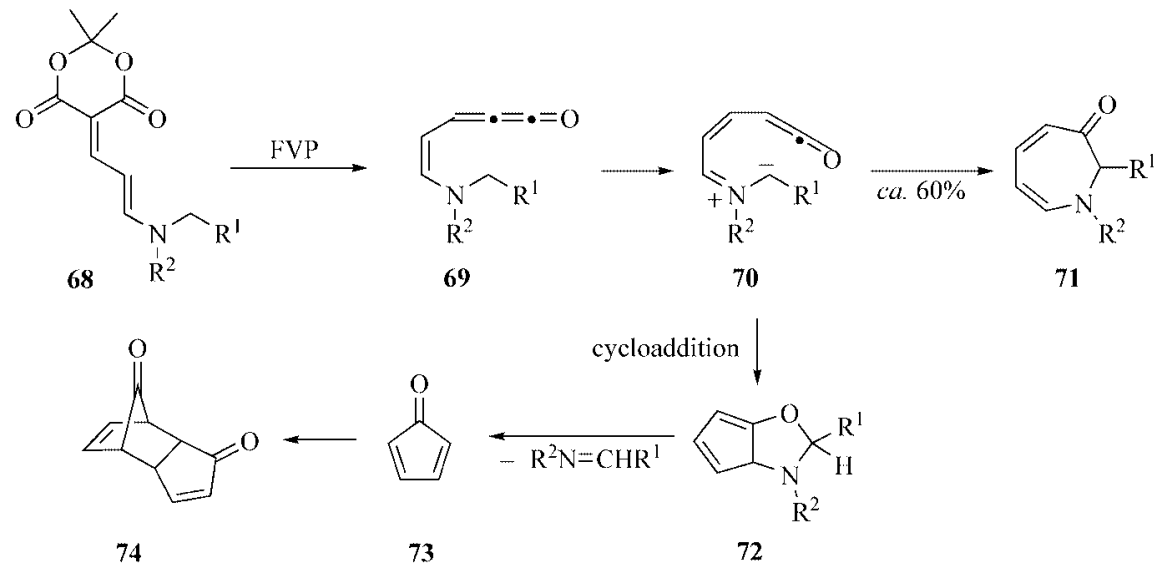

Scheme 15 .

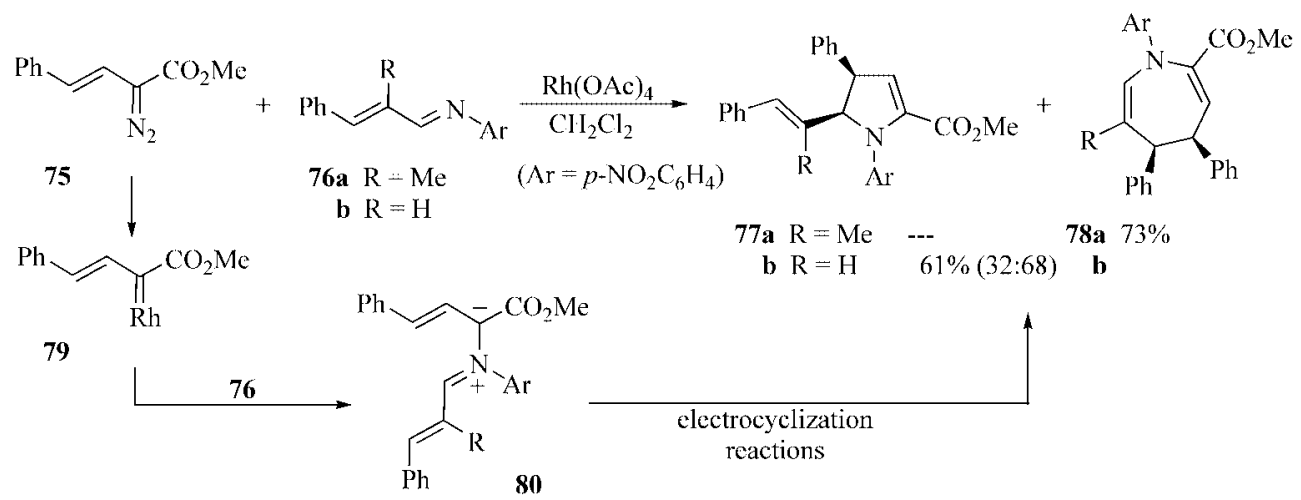

Scheme 16.

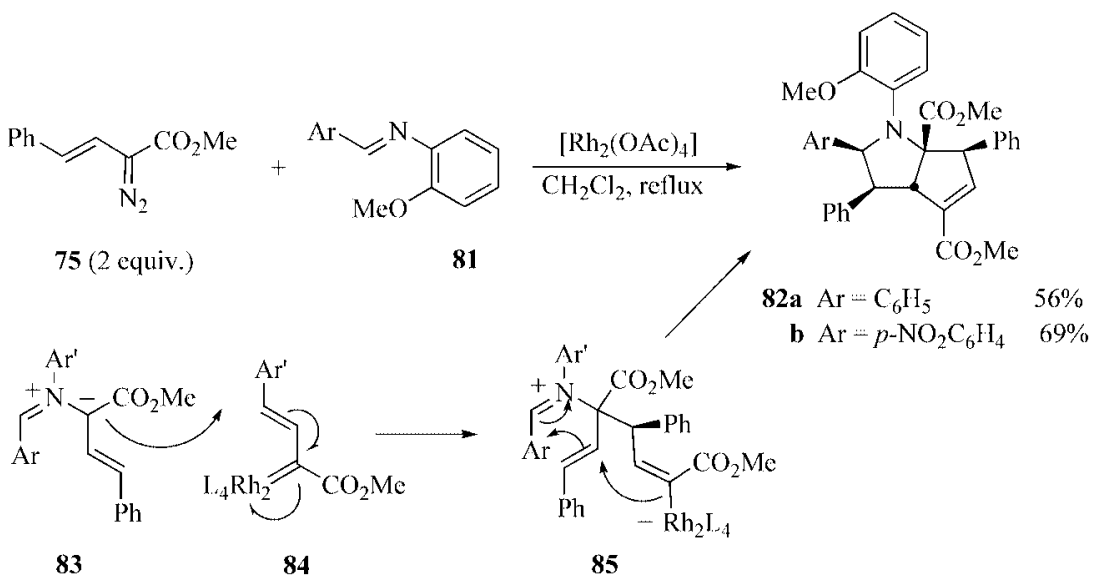

Scheme 17.

orbital-allowed reactions: the 1,6-sigmatropic shift of the allylic hydrogen, generating a conjugated azomethine ylide, $\mathbf{8 8}$, and its 1,7-electrocyclization (Scheme 18). ${ }^{[38-41]}$

The reaction of heterocyclic systems of type 91, bearing a chiral centre at the alkenyl moiety, reinforces the mechanistic interpretation concerning the concerted nature of the azepine formation. The reaction of chiral aldehyde 91 with D-1-phenylethylamine in benzene, in the presence of molecular sieves at room temperature, gives azepine $\mathbf{9 2}$ in $77 \%$ yield as a single isomer. The authors conclude that the chirality at the alkenyl moiety was conserved during the azepine ring formation, and was transferred to the 4- and 5 -positions of the azepine. Thus, the process shows high selectivity, as expected for a concerted cyclization (Scheme 19). ${ }^{[42]}$ This synthetic methodology for the construction of the azepine ring was extended to 3-(alkyl-2- 
<smiles>[R]C=CCN(C)C([Y])=C(C[Y])C([Y])=O</smiles><smiles>[R]C=CCN(Cc1ccccc1)c1c(C=N)c(=O)n(C)c(=O)n1C</smiles>

86a<smiles>[R]C=CCN(Cc1ccccc1)c1nc2ccccn2c(=O)c1C=[R]</smiles>

$86 \mathrm{c}$<smiles>[R]C=CC[N+](C)=C(C)C(C=CC)=CC</smiles>

87<smiles>[R]C=CCC(C)=C(C(C)=O)C([Y])=[N+](C)C</smiles>

88

Scheme 18.<smiles>[R]C=CCN(Cc1ccccc1)c1c(C=O)c(=O)oc2ccccc12</smiles><smiles>[Y]C(C)C1C([Y8])C([R])C=CN(C)C1C(C)=O</smiles>

89 4,5-cis-azepines<smiles>[R]C=CCN(Cc1ccccc1)c1cc(C)n(C)c(=O)c1C=[R]</smiles>

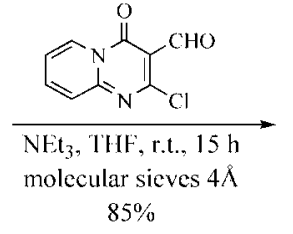

90<smiles>CCOC(=O)/C=C/C1CCCN1</smiles><smiles>CCOC(=O)/C=C/[C@H]1CCCN1c1nc2ccccn2c(=O)c1C=O</smiles>

91<smiles>[R1]N[C@@H]1c2c(nc3ccccn3c2=O)N2CCCC2=CC1C(=O)OCC</smiles>

$9277 \%$ (single isomer)

Scheme 19.

enyl)aminoacrolein derivatives and their imines, allowing the development of an efficient approach toward monocylic azepines. $^{[43-45]}$

1,5-Electrocyclization of conjugated azomethine ylides, generated from imines of $N$-benzyl- $N$-[3- $(N$-substituted imino)methyl-4-oxo-4H-pyrido[1,2-a]pyrimidin-2-yl]amino esters, provides an approach to 2,3-dihydropyrido[1,2-a]pyrrolo[2,3- $d]$ pyrimidin-4(1H)-ones. The authors optimised the reaction conditions to allow the selective formation of only one stereoisomer. One representative example is shown in Scheme 20. The 1,6-sigmatropic hydrogen shift allows the generation of the more stable azomethine ylide 95 and its disrotatory 1,5-electrocyclization reaction gives 2,3-cis pyrroline derivative 94. ${ }^{[46]}$

Nyerges et al. described the synthesis of the pyrrolo$[3,4-c]$ quinoline ring system (99 and 100) via 1,5-electrocyclization of azomethine ylides derived from 3-formylquinoline derivatives 96. The reaction of 2-chloro-3-formylquinoline (96a) with sarcosine in refluxing xylene gives 2methyl-2,4,5,9b-tetrahydro- $1 H$-pyrrolo[3,4-c] quinolin-4-one (100a) in moderate yields. The involvement of azomethine ylide intermediates, generated by the decarboxylation method, was confirmed by trapping the dipoles with $N$ phenylmaleimide. The azomethine ylides undergo 1,5-electrocyclization, followed by hydrolysis of the chlorine function. The 2-phenyl-3-formylquinolines show similar chemical behaviour, although in this case, the 1,5-electrocycliza-

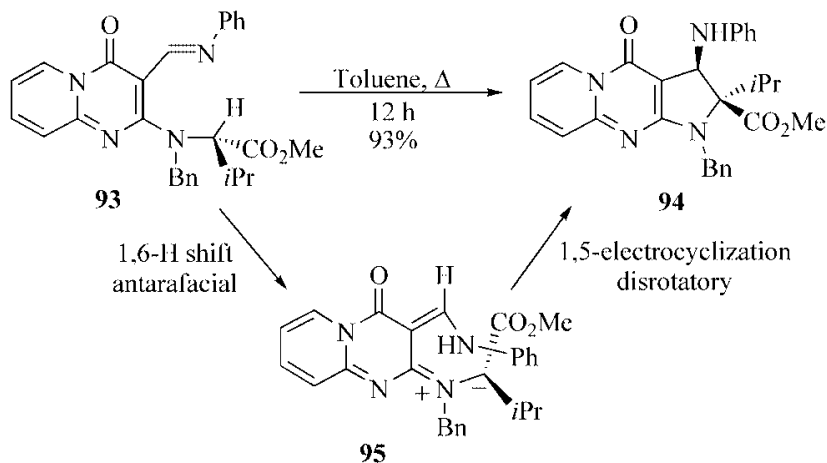

Scheme 20.

tion is followed by full aromatisation, giving 99. No evidence of 1,7-electrocyclization reactions was observed (Scheme 21). ${ }^{[47,48]}$

3,3-Diarylpropenals 101a and $N$-substituted $\alpha$-amino acids react, giving azomethine ylides via decarboxylation. The 1,7-electrocyclization of these intermediates, followed by a 1,5-hydrogen shift, affords 2,3-dihydro-5-phenyl- $1 \mathrm{H}$ benzazepines. The reactions with proline and pipecolinic acid give pyrrolo[1,2-a]benzazepine and pyrido[1,2-a][2]benzazepine, respectively. 1,7-Electrocyclization of azomethine ylides derived from 3-formylindoles (101b) and $\alpha$ amino acids provide a route to benz[5,6]azepino[4,3- $b$ ]indoles (Scheme 22). ${ }^{[49,50]}$ 


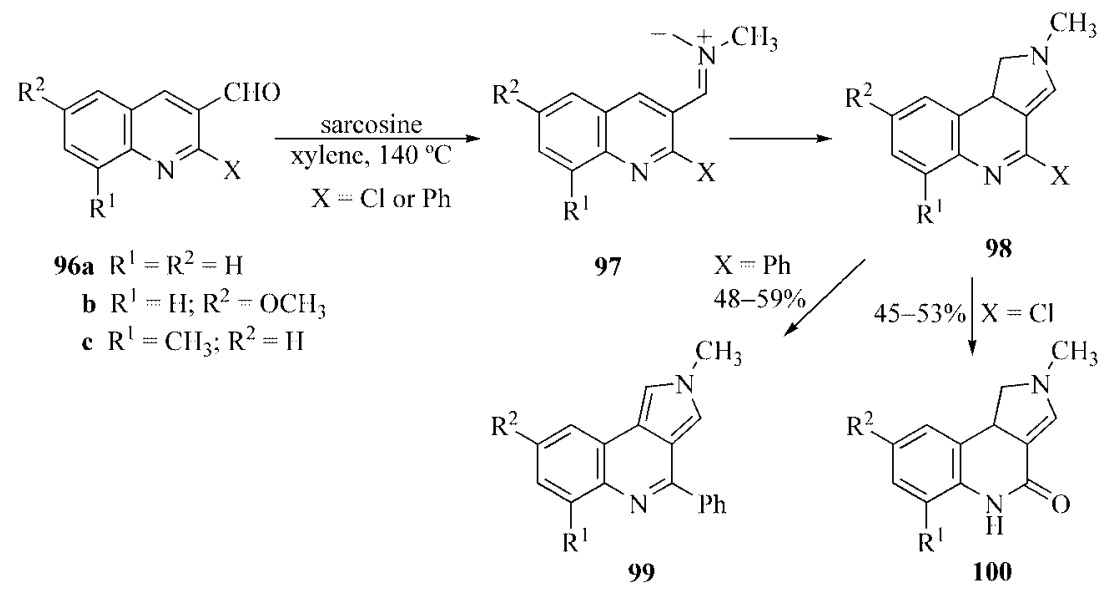

Scheme 21 .

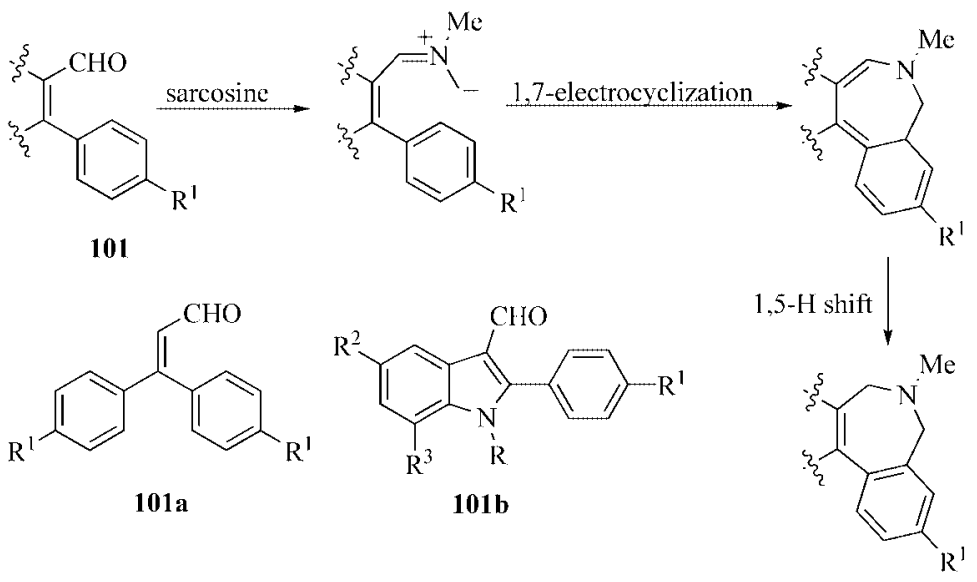

102a (from 101a) $94-99 \%$

102b (from 101b) $38-61 \%$

Scheme 22.

Stabilised $\alpha, \beta, \gamma, \delta$-unsaturated azomethine ylides 104, generated by the deprotonation method from isoquinolinium salts 103, undergo 1,7-electrocyclization giving tetrahydro[5,6]azepino[2,1-a] isoquinolines 106 (Scheme 23). ${ }^{[1]}$

The effect of the aryl substituent of isoquinoline salts 107 on the course of the electrocyclization process was also investigated. It was observed that the iminium salts $\mathbf{1 0 7}$ re- act with triethylamine at room temperature in dry ethanol to give the pyrrole derivatives 109 via 1,5-electrocyclization of the corresponding azomethine ylide intermediate (Scheme 24). ${ }^{[52]}$

Regiochemically controlled synthesis of substituted pyrroles can be achieved via 1,5-electrocyclization of vinyl azomethine ylides formed from the condensation of vinylogous<smiles>[R]C[N+]1=C(C=C(c2ccccc2)c2ccccc2)c2cc(OC)c(OC)cc2CC1</smiles><smiles>[R]C[N+]1=C(C=C(c2ccccc2)c2ccccc2)c2cc(OC)c(OC)cc2CC1</smiles><smiles>[X]C1C2C=CC=CC2=C(c2ccccn2)C=C2c3cc(OC)c(OC)cc3CCN21</smiles><smiles>[R]C1c2ccccc2C(c2ccccc2)=CC2c3cc(OC)c(OC)cc3CCN2C1[R]</smiles>

$\begin{array}{rlr}\text { 106a } \mathrm{R} & =\mathrm{CO}_{2} \mathrm{Mc} & 83 \% \\ \text { b } \mathrm{R}=\mathrm{CH}_{2} \mathrm{Ph} & 77 \% \\ \text { c } \mathrm{R} & =\mathrm{COPh} & 81 \% \\ \text { d } \mathrm{R} & \cdots \mathrm{CH}_{2} \mathrm{CH} \cdots \mathrm{CH}_{2} & 53 \%\end{array}$

Scheme 23 
<smiles>[R]C[N+]1=C(/C(=C/c2ccc([R])cc2[R])c2ccc([R])c([R])c2)c2cc(OC)c(OC)cc2CC1</smiles>

$\mathrm{R}^{5}=\mathrm{CO}_{2} \mathrm{Et}$ or $\mathrm{CH}=\mathrm{CH}_{2}$

$$
\begin{aligned}
& \text { 107a } R^{1}=O M e ; R^{2}=R^{3}=R^{4}=H \\
& \text { b } R^{1}=O M e ; R^{2}=R^{4}=H ; R^{3}=N_{2} \\
& \text { c } R^{1}=O M e ; R^{2}=R^{4}=H ; R^{3}=O M e \\
& \text { d } R^{1}=R^{2}=O M e ; R^{3}=H ; R^{4}=O \mathrm{OH}_{2} C H=\mathrm{CH}_{2}
\end{aligned}
$$

Scheme 24 .

iminium salts or their derivatives with $\alpha$-amino esters (Scheme 25). ${ }^{[53-55]}$ Reaction of 2-arylvinamidinium salts 110a with sarcosine gives 4-aryl-2-ethoxycarbonyl- $N$-substituted pyrroles 111, whereas starting with 1-arylvinamidinium salts $\mathbf{1 1 0 b}$ yields 2,3-disubstituted pyrroles 112. However, the reaction of 1-arylvinamidinium salts $\mathbf{1 1 0 b}$ with glycine ethyl ester leads to 2,5-disubstituted pyrroles 114. This regiochemistry was explained by considering that with primary amines, a 2:1 adduct may be formed from the reaction of $110 \mathrm{~b}$ with $\alpha$-amino esters, leading to azomethine ylide 113a. The 1,5-electrocyclization of this dipole allows the construction of the five-membered ring system. The same substitution pattern is observed in pyrroles obtained from the reaction of 3-aryl-3-chloropropeniminium salts $110 \mathrm{c}$ with $N$-substituted glycine derivatives. Thus, the same type of intermediate should be involved.

Disubstituted vinylogous iminium salt derivatives 116 can serve as precursors to 2,3,4-trisubstituted pyrrole systems. The chlorovinyl carbon of intermediate $\mathbf{1 1 7}$ is flanked by two groups, and is too sterically hindered to allow the nucleophilic addition of the amino ester. Therefore, azomethine ylides 118 are formed, and undergo 1,5-electrocyclization, followed by $\mathrm{HCl}$ elimination to give pyrroles 120 (Scheme 26). ${ }^{[56]}$

Conjugated azomethine ylides can be generated by a thermal 1,2-shift of the silyl group of $N$-silylmethylated-1azadienes 121. These dipoles undergo electrocyclization to afford $N$-silylated-2-pyrrolines $\mathbf{1 2 3}$, followed by hydrolysis

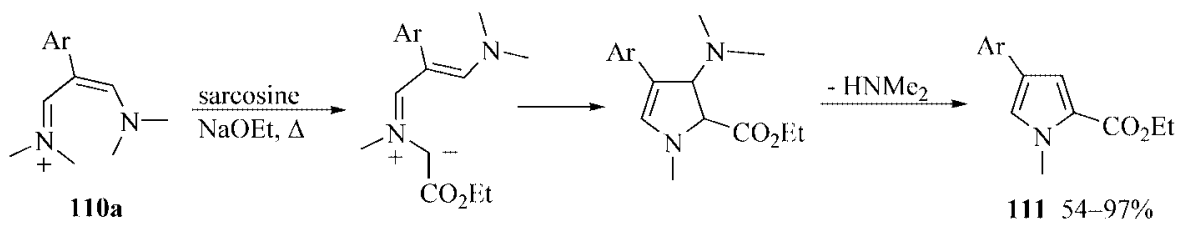

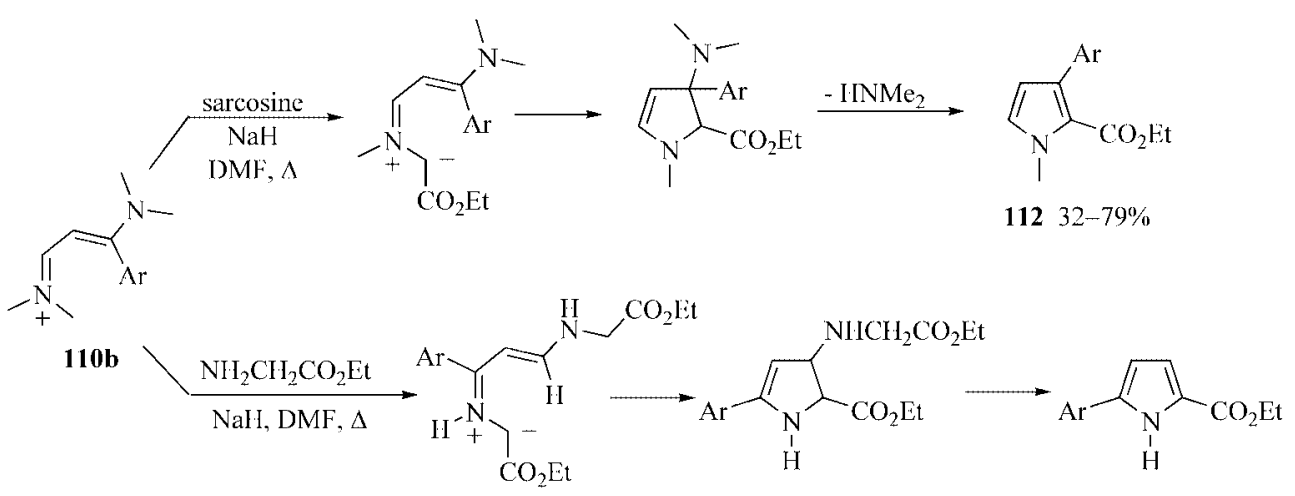

$113 a$

$11428-95 \%$<smiles>CN(C)/C=C\C(Cl)=[V]</smiles>

$110 \mathrm{c}$<smiles>CCOC(=O)C1C(N(C)C)C=C([Al])N1C</smiles>

$113 b$<smiles>CCOc1ccc([Al]C)n1C</smiles>

$11544-76 \%$

Scheme 25. 
<smiles>[R]/C(=C\N(C)C)C(=O)c1ccccc1</smiles><smiles>CCOCCCCOCC</smiles>

16<smiles>[R]/C(C=[N+](C)C)=C(/Cl)c1ccccc1</smiles><smiles>[R]NCC(=O)OCC</smiles><smiles>[R]C(=O)C[N+]([R4])=C([Tl])/C([R])=C(/Cl)c1ccccc1</smiles><smiles>[R]C(=O)C1N([R])C=C([R])C1(Cl)c1ccccc1</smiles>

119

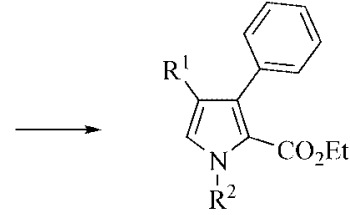

$12011-69 \%$

Scheme 26.

to give 1-pyrrolines 124 (Scheme 27). Azomethine ylides 122 can be trapped by a 1,3-dipolar cycloaddition reaction with $N$-phenylmaleimide. ${ }^{[57]}$

Trimethylsilylmethyliminium triflate 125, formed from the reaction of cinnamaldehyde $N$-arylimines with trimethylsilylmethyl trifluoromethanesulfonate, is obtained as mixtures of the $E, Z$ and $E, E$ isomers. Desilylation of these salts in the presence of dipolarophiles affords the corresponding 1,3-dipolar cycloadducts. The reactions with dimethyl maleate, dimethyl fumarate and $N$-arylmaleimides give equal mixtures of stereoisomeric substituted pyrrolidines. The stereochemical outcome of these reactions allowed the authors to conclude that the same dipole participates in the cycloaddition from either the $E, Z$ or the $E, E$ iminium salt precursor. The cycloaddition of $\mathbf{1 2 5}$ with DMAD gives 2,5-dihydropyrroles 127, which can be oxidised with $\mathrm{PbO}_{2}$ to 2styrylpyrroles 128 (Scheme 28). ${ }^{[58]}$
The synthesis of the bridged pyrrolidizine core of asparagamine A based on the intramolecular 1,3-dipolar cycloaddition of an azomethine ylide has been reported (Scheme 29). The 1,3-dipole $\mathbf{1 3 0}$ was generated upon treatment of vinylogous amide $\mathbf{1 2 9}$ with triflic anhydride, followed by desilylation with tetrabutylammonium triphenyldifluorosilicate (TBAT). The study was extended to the intermolecular cycloaddition of a range of vinylogous amides, and a variety of functionalised nitrogen-heterocycles was obtained. ${ }^{[59]}$

1,5-Electrocyclization of vinylazomethine ylides $\mathbf{1 3 3}$, generated from imines by 1,2-prototopy, gives dihydropyrroles 134, which can be efficiently converted into the corresponding pyrrole upon treatment with DDQ. The reaction of 1-vinyltetrahydroisoquinoline $\mathbf{1 3 5}$ with aldehydes affords 4,5-dihydropyrrolo[1,2-a]isoquinolines 139. The first step of

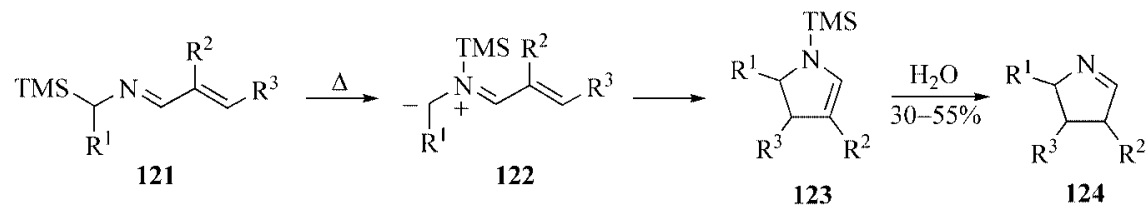

Scheme 27.
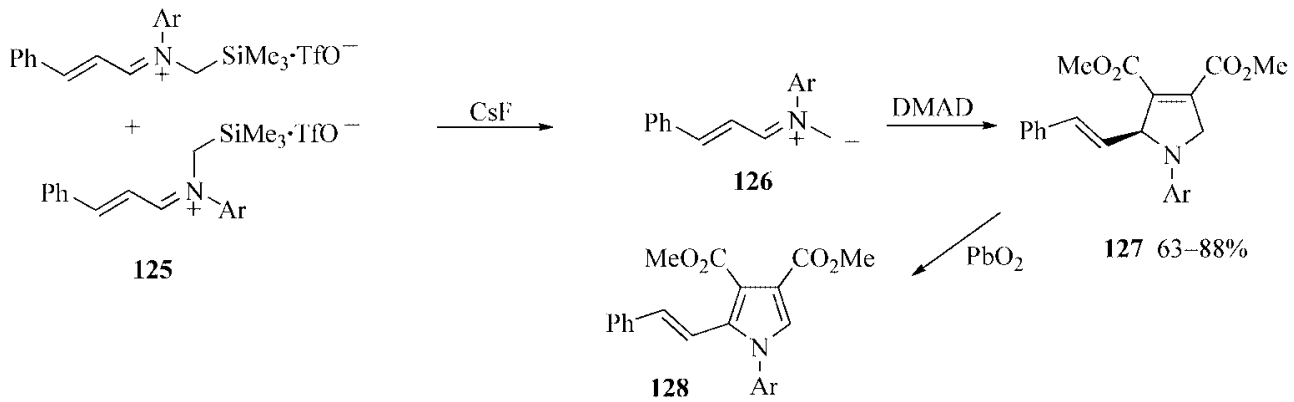

$12763-88 \%$

Scheme 28 


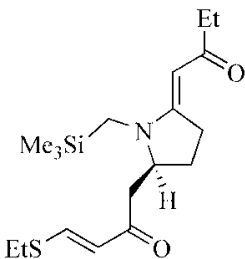

129
1. $\mathrm{Tf}_{2} \mathrm{O}, \mathrm{CHCl}_{3}$, r.t.

2. TBAT, $65^{\circ} \mathrm{C}, 24 \mathrm{~h}$

$$
\text { (1) }
$$

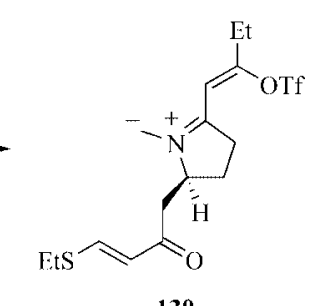

130

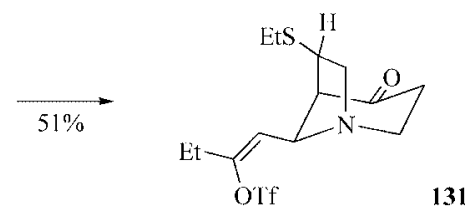

Scheme 29.

this synthesis is the formation of an iminium salt, followed by deprotonation, giving the 1,5-dipole 136. The enamine $\mathbf{1 3 7}$ is obtained from the 1,5-electrocyclization reaction, and the condensation with a second equivalent of the aldehyde, subsequent prototropy, and deprotonation gives the final product 139 (Scheme 30). ${ }^{[60]}$

The 1,5-electrocyclization reaction can also be carried out with vinyl azomethine ylides incorporating a heteroatom at either position of the vinyl group. That is the case of the 1,3-dipoles 141, generated by the decarboxylation of imines resulting from the condensation of $\alpha$-amino acids with 2,2-dipyridyl ketone (140). The cyclization, followed by aromatisation, gives 1,3-disubstituted-2-azaindolizines 142. The reaction of 1,2,3,4-tetrahydroquinoline $\mathbf{1 4 3}$ and divinyl ketone $\mathbf{1 4 4}$ in the presence of dibutyltin dichloride, acting as a mild Lewis acid, leads to the formation of vinyl

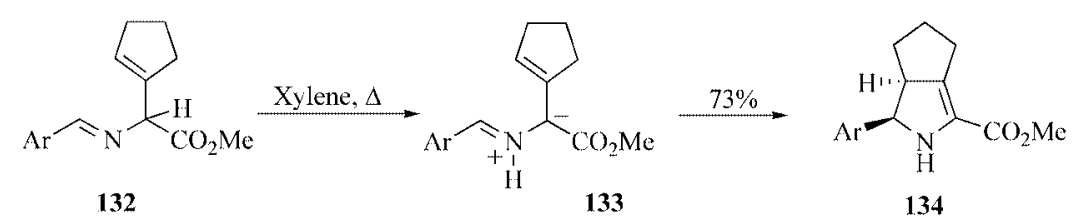

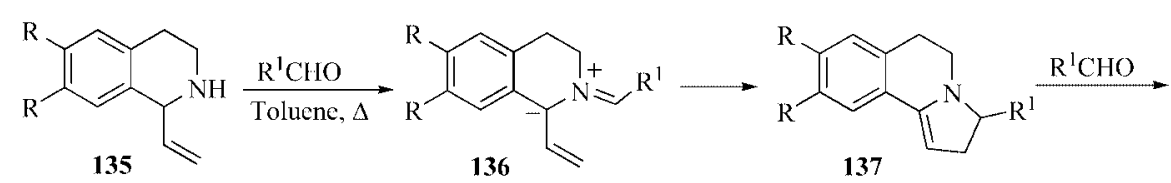<smiles>[R]Cc1cc([Y])n2c1-c1cc([R])c([R])cc1CC2</smiles>

Scheme 30.
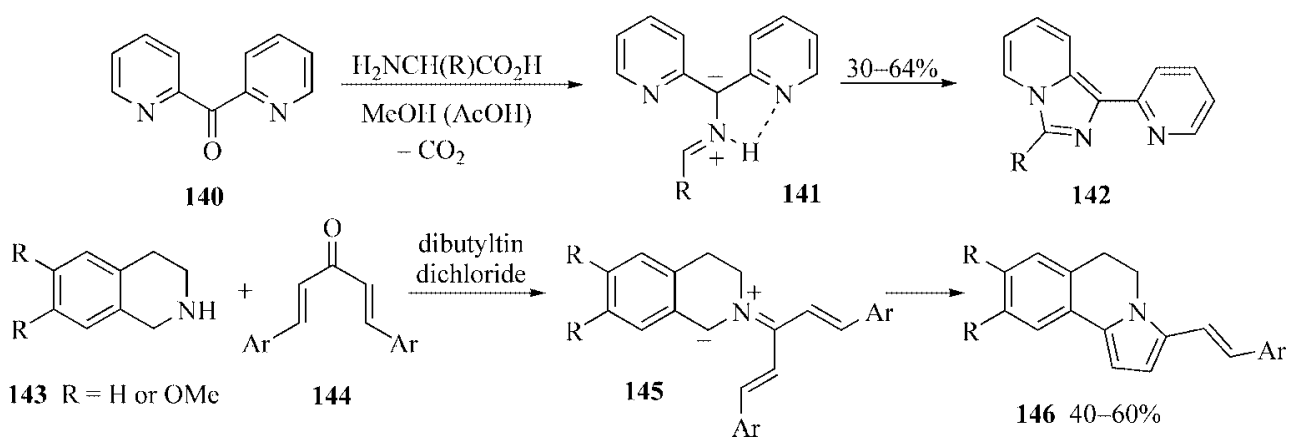

Scheme 31 .<smiles>[R]C=C([R])CN1CCc2ccccc2C1</smiles>

Scheme 32 . 
azomethine ylides $\mathbf{1 4 5}$. Their 1,5-electrocyclization results in the synthesis of 5,6-dihydropyrrolo[2,1-a]isoquinolines 146 (Scheme 31). ${ }^{[61]}$

$\mathrm{N}$-allyltetrahydroisoquinolines $\mathbf{1 4 7}$ undergo oxidation induced by silver carbonate, giving 6-dihydropyrrolo[2,1-a]isoquinolines 149, together with, in most cases, their corresponding isoquinolines 150. This is an example of 1,5-electrocyclization of an azomethine ylide followed by aromatisation. The same type of chemistry can be carried out with $N$-allyltetrahydro- $\beta$-carbolines (Scheme 32). ${ }^{[62]}$

\section{Extended Dipolar Systems}

The study of pericyclic reactions of extended dipoles (with more than $4 \pi$ electrons) is an almost unexplored research area. However, Storr and co-workers explored the reactivity of pyrrolo[1,2-c]thiazol 2,2-dioxides 151 and proved that they can be considered as masked azafulvenium methides (152). ${ }^{[63]}$ Earlier, Padwa and co-workers described unsuccessful attempts to extrude $\mathrm{SO}_{2}$ from pyrrolo[1,2-c]thiazol 2,2-dioxides for the generation of an azafulvenium methide, both thermally $\left(300^{\circ} \mathrm{C}\right)$ and photochemically. ${ }^{[64]}$ These systems can be considered as "higher-order" azomethine ylides and, in principle, can act as $4 \pi$ 1,3-dipoles or as $8 \pi 1,7$-dipoles.<smiles>[R]C1N([O-])C2([R])[R]C1([R])n1cccc12</smiles>

151<smiles>[R]C([R])=C1C=CC=[N+]1[CH]C</smiles>

152
Storr and co-workers found that the generation of 1-azafulvenium methides $(154,157,160$ and 163) by the thermal extrusion of sulfur dioxide from pyrrolo[1,2-c]thiazol 2,2-dioxides could be achieved under flash vacuum pyrolysis (FVP) reaction conditions. They described the first evidence for the trapping of these transient 1-azafulvenium methide systems in pericyclic reactions. The extended dipolar systems 154, 157 and $\mathbf{1 6 0}$ undergo sigmatropic 1,8$\mathrm{H}$ shifts, giving vinylpyrroles, and the acyl derivatives 163 electrocyclise to give pyrrolo[1,2-c]-[1,3]oxazines $\mathbf{1 6 4}$ (Scheme 33). ${ }^{[63]}$

The generation and reactivity of azafulvenium methides was further studied. The authors found that vinylpyrrole 155 could be obtained in $61 \%$ yield via azafulvenium methide 154 by carrying out the reaction in a sealed tube, proving that sulfone $\mathbf{1 5 3}$ extrudes sulfur dioxide without the need for FVP conditions. The study of the flash vacuum pyrolysis of sulfone $\mathbf{1 5 3}$ led to a different outcome than the previously reported result, the synthesis of methyl 1,3dimethyl-5-oxo-5H-pyrrolizine-2-carboxylate (165). The vi-<smiles>C=Cn1c(C)c(C(=O)OC)c(C(=O)OC)c1C</smiles>

153<smiles>[M]C1c2c(C(=O)OC)c(C(C)=O)c(C)n2CS1(=O)=O</smiles>

154

155<smiles>C=Cc1c(C(=O)[Na])c(C(C)=O)c(C)n1C</smiles>

156

157

158<smiles>COC(=O)c1c(C(=O)OC)c2n(c1C)CC(C)(C)C2(C)C</smiles><smiles>COC(=O)c1c(C(=O)OC)n2[n+](c1C)CCNCC2</smiles><smiles>C=C(C)c1c(C(C)=O)c(C(C)=O)c(C)n1C</smiles>

159

160

161

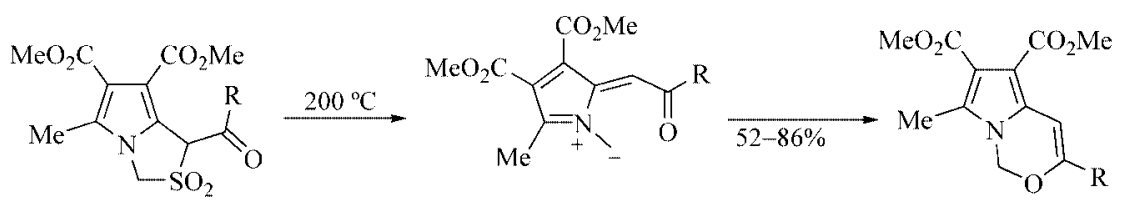

162

163

164 
nylpyrrole $\mathbf{1 5 5}$ is an intermediate in the formation of compound 165 from sulfone 153 since its pyrolysis gives the $5 \mathrm{H}$ pyrrolizine 165 in good yield. The thermolysis of 166 carried out in a sealed tube led to $N$-vinylpyrrole 168 in $43 \%$ yield. On the other hand, compound 168 was converted into 5 -oxo-5H-pyrrolizine 169 on FVP (44\%). The same product was obtained from the FVP of $\mathbf{1 6 6}$ (Scheme 34). ${ }^{65,66]}$ The formation of 5-oxo-5 $\mathrm{H}$-pyrrolizines from $\mathrm{N}$-vinylpyrroles can be rationalised by considering the formation of pyrrol-2-ylpropionate intermediates, formed from the $N$-vinylpyrroles through a sequence of sigmatropic shifts. The pyrrol-2-ylpropionates undergo concerted elimination of methanol, giving pyrrol-2-ylidene ketenes, which are converted into pyrrolizinones by electrocyclisation. ${ }^{[65,66]}$

The cheletropic extrusion of $\mathrm{SO}_{2}$ from the 3-phenyl- $1 \mathrm{H}$ pyrrolo[1,2-c]thiazol 2,2-dioxides $\mathbf{1 7 0}$ could be carried out in a sealed tube leading to styryl- $1 H$-pyrroles 173 . The formation of styryl-1H-pyrroles $\mathbf{1 7 3}$ can be explained by considering the generation of azafulvenium methides 171, followed by a 1,7-electrocyclic reaction, giving $\mathbf{1 7 2}$, which re- arranges to the final products. Sulfone 170a is converted into methyl 2-methyl-4-oxo-1,4-dihydro-1-azabenzo[f]azulene-3-carboxylate (174a) on flash vacuum pyrolysis. Under sealed-tube reaction conditions, styryl- $1 H$-pyrrole 173a is formed and converted into a pyrrole fused to a benzocyclohepten-5-one ring system. This was confirmed by promoting the FVP of styryl- $1 H$-pyrrole 173a, which also gave compound 174a (31\%). 3-Phenyl- $1 H$-pyrrolo[1,2c] thiazol 2,2-dioxide (170b) showed a chemical behaviour similar to the one observed for compound 170a, and the corresponding 4-oxo-1,4-dihydro-1-azabenzo[f]azulene-3carboxylate (174b) could be obtained on FVP, although in low yield (Scheme 35). ${ }^{65,66]}$

Padwa et al. reported unsuccessful attempts to extrude sulfur dioxide from pyrrolo[1,2-c] thiazol 2,2-dioxide $\mathbf{1 7 5}$ by solution-phase thermolysis $\left(300^{\circ} \mathrm{C}\right) .{ }^{[64]}$ Storr et al. attempted the flash vacuum pyrolysis, considering that this unsuccessful result was due to the high thermal stability of this sulfone, characterised by low bond order of the 3,4bond of the sulfolene moiety. ${ }^{[63]}$ Although sulfur dioxide

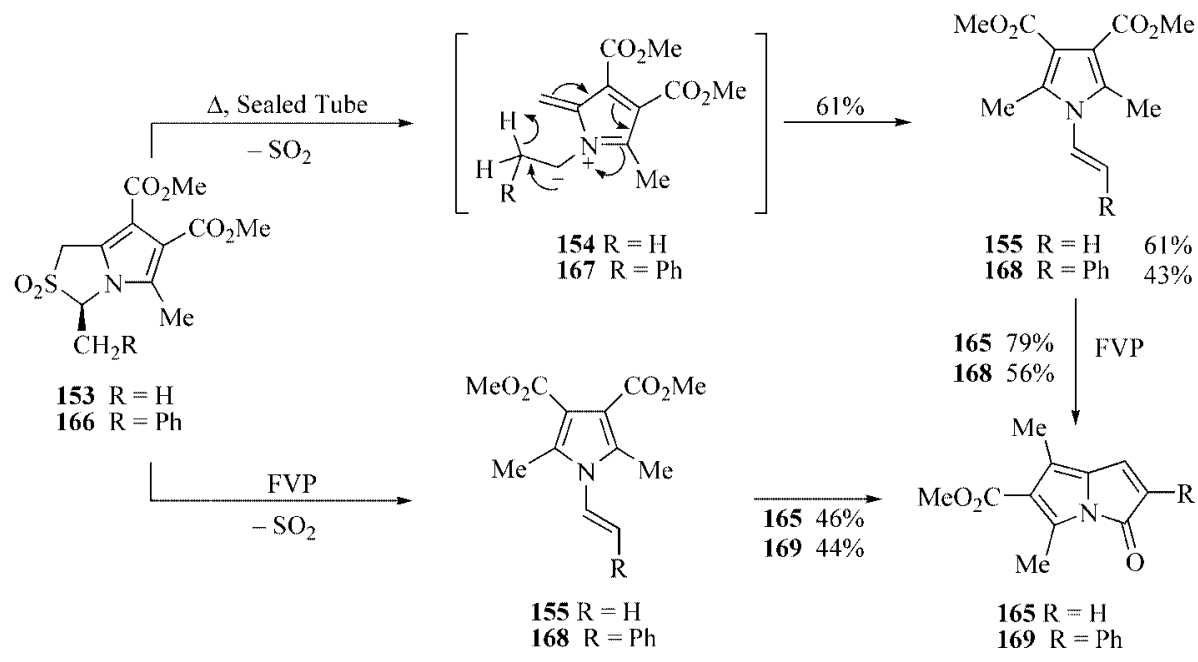

Scheme 34 .

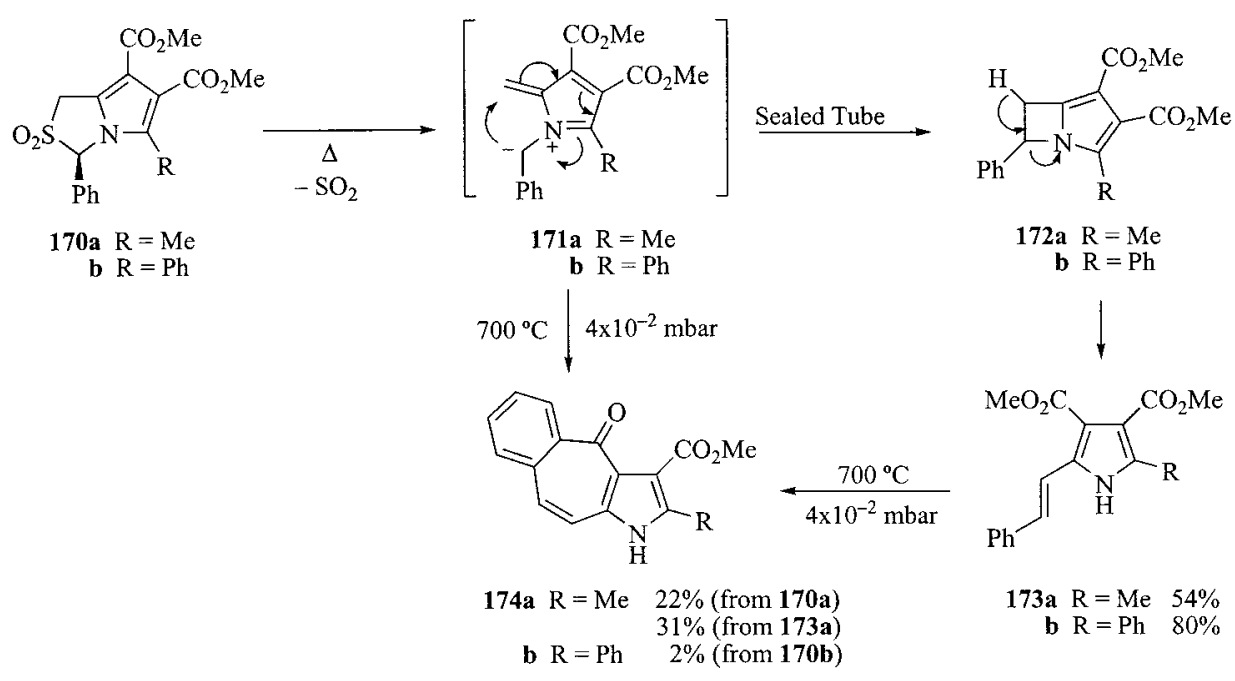

Scheme 35 . 

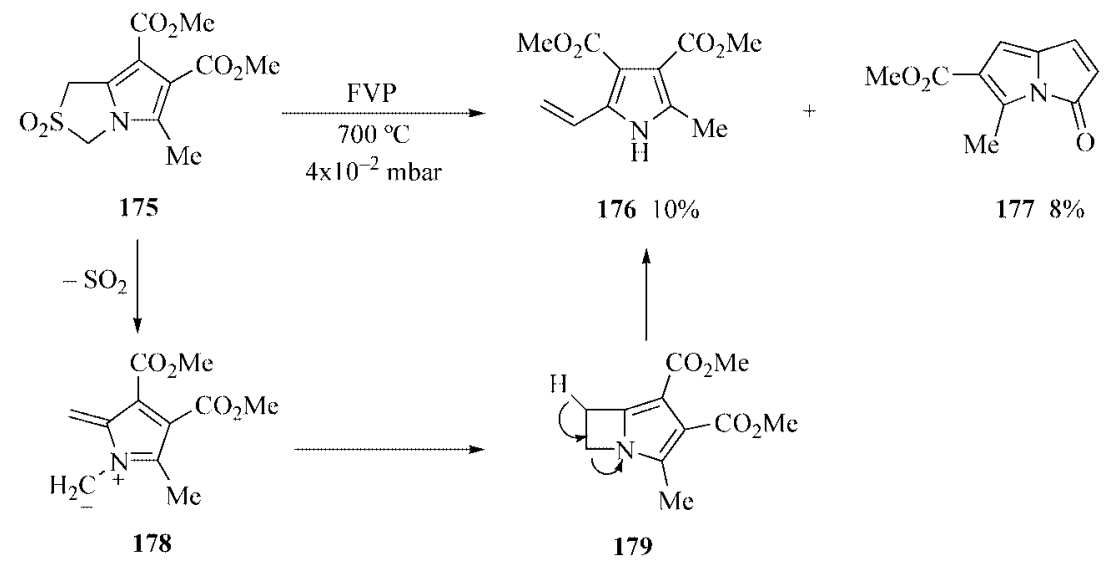

Scheme 36

was eliminated from sulfone $\mathbf{1 7 5}$, no identifiable products were detected. Under the FVP conditions described by Pinho e Melo et al., two products are obtained from pyrrolo[1,2-c] thiazol 2,2-dioxide $\mathbf{1 7 5}$, the $C$-vinylpyrrole $\mathbf{1 7 6}$ and 5-oxo-5H-pyrrolizine 177, although in low yields. The 1-azafulvenium methide $\mathbf{1 7 8}$ does not have a proton in the appropriate position to allow the suprafacial $1,8-\mathrm{H}$ shift of the type described in Scheme 33 for the synthesis of $\mathrm{N}$-vinylpyrroles. Therefore, the process occurs via an alternative route: a 1,7-electrocyclic reaction gives $\mathbf{1 7 9}$, which undergoes a rearrangement to pyrrole 176. This is a mechanistic pathway similar to the one described for the phenyl derivatives 171. The mechanistic interpretation for the synthesis of 5-oxo-5 $\mathrm{H}$-pyrrolizine $\mathbf{1 7 7}$ from $\mathbf{1 7 6}$ has been reported (Scheme 36). ${ }^{[66]}$

\section{Conclusion}

This review deals with the chemistry of conjugated azomethine ylides. A wide range of synthetic approaches to the generation of vinyl azomethine ylides and butadienyl azomethine ylides is now available, allowing wide applicability of the use of these intermediates for the synthesis of nitrogen heterocycles. The reactivity pattern of the conjugated azomethine ylides includes 1,3-dipolar cycloaddition, 1,5electrocyclization and 1,7-electrocyclization, with high stereoselectivity in most cases. Thus, it is a powerful strategy for the synthesis of monocyclic and annulated five- and sevenmembered nitrogen-heterocyclic compounds.

Pericyclic reactions of azafulvenium methides - "higherorder" azomethine ylides - are an interesting approach to functionalised pyrroles. The intramolecular trapping of these transient $8 \pi$ 1,7-dipoles in pericyclic reactions, namely sigmatropic 1,8-hydrogen shifts and 1,7-electrocyclizations, allows the synthesis of $N$-vinylpyrroles and $C$-vinylpyrroles, which under flash vacuum pyrolysis conditions, are converted into 5-oxo-5H-pyrrolizines and 4-oxo-1,4-dihydro-1aza-benzo[f]azulenes, respectively.

\section{Acknowledgments}

We thank Chymiotechnon and Fundação para a Ciência e a Tecnologia (POCI/QUI/55584/2004) for financial support.

[1] R. Huisgen, Angew. Chem. Int. Ed. Engl. 1963, 2, 565-632.

[2] R. R. Woodward, R. Hoffmann, Angew. Chem. Int. Ed. Engl. 1969, 8, 781-853.

[3] a) K. N. Houk, J. Sims, R. E. Duke, R. W. Strozier, J. K George, J. Am. Chem. Soc. 1973, 95, 7287-7301; b) K. N. Houk, J. Sims, C. R. Watts, L. J. Luskus, J. Am. Chem. Soc. 1973, 95, 7301-7315.

[4] K. V. Gothelf, K. A. Jørgensen, Chem. Rev. 1998, 98, 863-909.

[5] A. Padwa, In: Comprehensive Organic Synthesis (Eds.: B. M. Trost, L. Fleming); Pergamon, Oxford, U. K., 1991, Vol. 4, p.1069.

[6] P. A. Wade, In: Comprehensive Organic Synthesis (Eds.: B. M. Trost, L. Fleming); Pergamon, Oxford, U. K., 1991, Vol. 4, p.1111.

[7] I. Coldham, R. Hufton, Chem. Rev. 2005, 105, 2785-2809.

[8] C. Nájera, J. M. Sansano, Curr. Org. Chem. 2003, 7, 1105-1150.

[9] E. Vedejs In Advances in Cycloaddition, D. P Curran, JAI Press INC., 1988, Vol. 1, p. 33-51.

[10] F. Kröhnke, Angew. Chem. 1953, 65, 605-627.

[11] F. Kröhnke, Ber. Dtsch. Chem. Ges. 1934, 67, 656-667.

[12] K. W. Ratts, R. K. Howe, W. G. Phillips, J. Am. Chem. Soc. 1969, 91, 6115-6121.

[13] a) X. Wei, Y. Hu, T. Li, H. Hu, J. Chem. Soc., Perkin Trans. 1 1993, 2487-2489; b) B. Wang, X. Zhang, J. Li, X. Jiang, Y. Hu, H. Hu, J. Chem. Soc., Perkin Trans. 1 1999, 1571-1575; c) A. L. Katritzky, G. Qiu, B. Yang, H.-Y. He, J. Org. Chem. 1999, 64, 7618-7621; d) L. Zhang, F. Liang, L. Sun, Y. Hu, H. Hu, Synthesis 2000, 1733-1737; e) S. Zhao, M. G. P. M. S. Neves, A. C. Tomé, A. M. S. Silva, J. A. S. Cavaleiro, Tetrahedron Lett. 2005, 46, 5487-5490.

[14] E. C. Taylor, I. J. Turchi, Chem. Rev. 1979, 79, 181-231.

[15] R. Huisgen, Angew. Chem. Int. Ed. Engl. 1980, 19, 947-973.

[16] D. N. Reinhoudt, W. P. Trompenaars, J. Geevers, Tetrahedron Lett. 1976, 17, 4777-4780.

[17] I. Coldham, A. J. Collis, R. J. Mould, D. E. Robinson, Synthesis 1995, 1147-1150.

[18] G. J. Rowlands, W. K. Barnes, Tetrahedron Lett. 2004, 45, 5347-5350.

[19] W. Friebolin, W. Eberbach, Tetrahedron 2001, 57, 4349-4358.

[20] W. Friebolin, W. Eberbach, Helv. Chim. Acta 2001, 84, 38223836.

[21] W. Augstein, F. Kröhnke, Justus Liebigs Ann. Chem. 1966, 697, $158-170$. 
[22] K. Marx, W. Eberbach, Tetrahedron 1997, 53, 14687-14700.

[23] K. Marx, W. Eberbach, Chem. Eur. J. 2000, 6, 2063-2068.

[24] W. Maier, W. Eberbach, Helv. Chim. Acta 1991, 74, 1095-1101.

[25] B. de Boeck, H. G. Viehe, Tetrahedron 1998, 54, 513-520.

[26] L. R. Domingo, M. J. Aurell, Tetrahedron 2001, 57, 169-177.

[27] W. Klop, L. Brandsma, J. Chem. Soc., Chem. Commun. 1983, 988-989.

[28] T. Mayer, G. Maas, Tetrahedron Lett. 1992, 33, 205-208.

[29] R. Reinhard, M. Glaser, R. Neumann, G. Maas, J. Org. Chem. 1997, 62, 7744-7751.

[30] M. Reisser, G. Maas, J. Org. Chem. 2004, 69, 4913-4924.

[31] H. Dhimane, J. C. Pommelet, J. Chuche, G. Lhommet, M. G. Richaud, M. Haddad, Tetrahedron Lett. 1985, 26, 833-836.

[32] H. McNab, L. C. Monahan, J. Chem. Soc., Perkin Trans. 1 1988, 863-868.

[33] H. McNab, M. Morrow, ARKIVOC 2002, VIII, 125-133.

[34] H. McNab, L. C. Monahan, T. Gray, J. Chem. Soc., Chem. Commun. 1987, 140-141.

[35] M. P. Doyle, W. Hu, D. J. Timmons, Org. Lett. 2001, 3, 37413744.

[36] M. P. Doyle, M. Yan, W. Hu, L. S. Gronenberg, J. Am. Chem. Soc. 2003, 125, 4692-4693.

[37] M. Yan, N. Jacobsen, W. Hu, L. S. Gronenberg, M. P. Doyle, J. T. Colyer, D. Bykowski, Angew. Chem. Int. Ed. 2004, 43, 6713-6716.

[38] T. Inazumi, E. Harada, T. Mizukoshi, Y. Kuroki, A. Kakehi, M. Noguchi, J. Chem. Soc., Perkin Trans. 1 1994, 565-570.

[39] Y. Kuroki, Tetrahedron 1994, 50, 1063-1072.

[40] M. Noguchi, T. Mizukoshi, A. Kakehi, Tetrahedron 1996, 52, 13081-13096.

[41] M. Noguchi, T. Mizukoshi, T. Uchida, Y. Kuroki, Tetrahedron 1996, 52, 13097-13110.

[42] M. Noguchi, T. Mizukoshi, S. Nakagawa, A. Kakehi, Tetrahedron 1996, 52, 13111-13120.

[43] M. Noguchi, R. Matsushita, S. Takamura, T. Uchida, A. Kakehi, M. Shiro, H. Yamamoto, Tetrahedron Lett. 2000, 41, 8489-8493.

[44] M. Noguchi, H. Yamada, S. Takamura, K. Okada, A. Kakehi, H. Yamamoto, Tetrahedron 2000, 56, 1299-1307.

[45] M. Noguchi, H. Yamada, S. Takamura, T. Uchida, M. Hironaka, A. Kakehi, H. Yamamoto, Eur. J. Org. Chem. 2000, 1489-1496.

[46] M. Noguchi, M. Shirai, K. Nakashima, I. Arai, A. Nishida, H. Yamamoto, A. Kakahi, Tetrahedron 2003, 59, 4581-4590.

[47] M. Nyerges, Á. Pintér, A. Virányi, G. Blaskó, L. Töke, Tetrahedron 2005, 61, 8199-8205.
[48] Á. Pintér, M. Nyerges, A. Virányi, L. Töke, Tetrahedron Lett. 2003, 44, 2343-2346.

[49] A. Arany, P. Groudwater, M. Nyerges, Tetrahedron Lett. 1998 , 39, 3267-3268.

[50] M. Nyerges, Á. Pintér, A. Virányi, I. Bitter, L. Töke, Tetrahedron Lett. 2005, 46, 377-380.

[51] M. Nyerges, A. Virányi, Á. Pintér, L. Töke, Tetrahedron Lett. 2003, 44, 793-794.

[52] M. Nyerges, L. Töke, Tetrahedron Lett. 2005, 46, 7531-7534.

[53] J. T. Gupton, D. A. Krolikowski, R. H. Yu, S. W. Riesinger, J. Org. Chem. 1990, 55, 4735-4740.

[54] J. T. Gupton, S. A. Petrich, L. L. Smith, M. A. Bruce, P. Vu, K. X. Du, E. E. Dueno, C. R. Jones, J. A. Sikorski, Tetrahedron 1996, 52, 6879-6892.

[55] J. T. Gupton, D. A. Krolikowski, R. H. Yu, P. Vu, J. A. Sikorski, M. L. Dahl, C. R. Jones, J. Org. Chem. 1990, 55, 54805483.

[56] J. T. Gupton, K. E. Krumpe, B. S. Burnham, K. A. Dwornik, S. A. Petrich, K. X. Du, M. A. Bruce, P. Vu, M. Vargas, K. M. Keertikar, K. N. Hosein, C. R. Jones, J. A. Sikorski, Tetrahedron 1998, 54, 5075-5088.

[57] M. Ohno, H. Miyata, M. Komatsu, Y. Ohshiro, Tetrahedron Lett. 1991, 32, 5093-5096.

[58] R. N. Butler, D. M. Farrell, J. Chem. Research (S) 1998, 8283.

[59] M. T. Epperson, D. Y. Gin, Angew. Chem. Int. Ed. 2002, 41, $1778-1780$.

[60] R. Grigg, H. Q. Nimal Gunaratne, D. Henderson, V. Sridharan, Tetrahedron 1990, 46, 1599-1610.

[61] R. Grigg, P. Kennewell, V. Savic, V. Sridharan, Tetrahedron 1992, 48, 10423-10430.

[62] R. Grigg, P. Myers, A. Somasunderan, V. Sridharan, Tetrahedron 1992, 48, 9735-9744.

[63] a) O. B. Sutcliffe, R. C. Storr, T. L. Gilchrist, P. Rafferty, A. P. A. Crew, Chem. Commun. 2000, 675-676; b) O. B. Sutcliffe, R. C. Storr, T. L. Gilchrist, P. Rafferty, J. Chem. Soc., Perkin Trans. 1 2001, 1795-1806.

[64] A. Padwa, G. E. Fryxell, J. R. Gasdaska, M. K. Venkatramanan, G. S. K. Wong, J. Org. Chem. 1989, 54, 644-652.

[65] T. M. V. D. Pinho e Melo, M. I. L. Soares, A. M. d'A. Rocha Gonsalves, H. McNab, Tetrahedron Lett. 2004, 45, 38893893.

[66] T. M. V. D. Pinho e Melo, M. I. L. Soares, A. M. d'A. Rocha Gonsalves, J. A. Paixão, A. Matos Beja, M. Ramos Silva, J. Org. Chem. 2005, 70, 6629-6638.

Received: November 14, 2005

Published Online: March 13, 2006 